\title{
Rule of Law vs. Poland and Hungary - an Inconsistent Approach?
}

\begin{abstract}
NASIYA DAMINOVA*
Abstract. The first attempts of the European Commission and Parliament to invoke Art. 7(1) of the Treaty on European Union against the Polish and Hungarian governments demonstrate the EU's political willingness to claim its own authority in defending core European values (Art. 2 TEU) in case of state disobedience. However, despite these attempts to integrate the Rule of Law concept into the overall EU's supervisory machinery, the Commission's and the Parliament's submissions indicate a lack of coherency in implementing the principle as a relevant tool to address multiple challenges arising within the EU Member States legal systems. The parallel developments in the CJEUs case-law (LM/ML, Torubarov) support this statement. Regardless of the Council's yes/ no decisions in the Polish and Hungarian cases, these lines of reasoning are capable of giving rise to further questions in application of the European Arrest Warrant Framework decision or the Asylum Procedures Directive, in particular the EU Member States which remain within the scope of the EU's attention in view of systemic Human Rights violations (Italy, Romania, Bulgaria, Croatia). Moreover, the series of the CJEU's judgements on the Polish judicial reform are capable of paving the way to the de facto intervention into traditional areas of the EU Member States competence - the organisation of the national judicial systems, in light of the development of a EU-specific principle of effective judicial review.
\end{abstract}

Keywords: Article 7 TEU, Rule of Law, Hungary, Poland, backsliding

\section{INTRODUCTION}

The Rule of Law principle has been interpreted as part of the common constitutional traditions of the Member States since the first days of the European Union's formation. ${ }^{1}$ This stems from their participation in the European Convention on Human Rights (ECHR); their obligation to follow case law of the European Court of Human Rights (ECtHR $)^{2}$ and thus, from the broader perspective, is also rooted in the European legal culture. ${ }^{3}$ The EU legislatory and the EU Court of Justice (CJEU) have adopted a traditional approach to the Rule of Law concept being a tool to respond to the arbitrary use of state power whilst

* Postdoctoral researcher, Lehrstuhl für Öffentliches Recht mit internationaler Ausrichtung, Universität Konstanz, PhD in Comparative and Transnational Law, Scuola Superiore Sant 'Anna (2018), e-mail: nasiya.daminova@gmail.com. This paper was produced thanks to the Joint Postdoctoral Fellowship in Law 2018/19 (Hungarian Academy of Sciences Centre for Social Sciences Institute for Legal Studies/ Pázmány Péter Catholic University Faculty of Law and Political Sciences), and is current as of 31 July 2019. The author would like to thank Dr. Fruzsina Gárdos-Orosz, Dr. Ernő Várnay, Dr. Márton Varju, Dr. Balázs Fekete, Dr. Mónika Papp and Dr. Emese Szilágyi for their constructive comments on the earlier version of the paper draft. All possible mistakes remain the sole responsibility of the author of course.

1 Pech (2009) 4-5, 22-46.

2 Art. 46 of the Convention for the Protection of Human Rights and Fundamental Freedoms, as amended by Protocols Nos 11 and 14 supplemented by Protocols Nos 1, 4, 6, 7, 12 and 13 (European Convention on Human Rights) [1950] Europ.T.S. No. 5; 213 U.N.T.S. 221. For the res interpretata effect of the European Court of Human Rights Judgments, see for example Arnardóttir (2017) 819-43.

3 Schroeder (2016) 5-27. 
considering the specificity of the EU's sui generis legal order. ${ }^{4}$ Hence, this general principle of EU Law aimed to guarantee an effective protection of natural and legal persons against illegal acts of the EU and of EU Member States acting within the scope of EU Law. ${ }^{5}$

While the EU has direct legal authority to guarantee the compliance of the Member States with this principle via the Art. 7 of the Treaty on European Union (TEU) mechanism, primarily indirect means of pressure i.e., the infringement procedures ${ }^{6}$ were resorted to for a long period of time. ${ }^{7}$ The first attempts of the European Commission and Parliament to invoke Art. 7(1) TEU ${ }^{8}$ against the Polish and the Hungarian government thus demonstrate the EU's political willingness to claim its own authority in defending core European values in the national legal systems. The Rule of Law concept seems to be the main tool for these interventions. Two key EU institutions built their reasoning around this notion while trying to convince the Council to determine the existence of a clear risk of a serious breach by Poland and Hungary of the rule of law 9 'and values on which the Union is founded'. ${ }^{10}$

Despite these attempts to integrate the Rule of Law concept into the overall EU's supervisory machinery, the Commission's and the Parliament's submissions arguably indicate a lack of coherency in approaching the principle as a relevant tool to address multiple challenges in the EU Member States' legal systems. ${ }^{11}$ The author claims that the approach of the pending Art. 7(1) TEU proposals differs significantly as the Commission's reasoning (Poland) is rather well founded, whilst the Parliament's argumentation (Hungary) seems incomparably less convincing and more policy-oriented. The parallel developments in the CJEU's case-law ( $L M / M L$, Torubarov) give rise to further questions regarding the application of the European Arrest Warrant Framework decision or the Asylum Procedures Directive - in particular, in the States which remain within the scope of the EU's attention in view of systemic Human Rights violations (Italy, Romania, Bulgaria, Croatia). ${ }^{12}$ Moreover, the series of CJEU judgements on the Polish judicial reform are capable of paving the way to a de facto intervention into traditional areas of the EU Member States' competence, namely the organisation of the national judicial systems, developing an EU-specific principle of effective judicial review.

To illustrate these developments the substance of the Rule of Law principle in the EU's autonomous legal order is analysed in view of its origins and the rationales behind its gaining a foothold in EU Law. This paper then probes the reasoning adopted by the European Commission (Poland) and by the Parliament (Hungary) proposals in accordance

4 Pech (2009) 5.

5 Jakab (2016) 188-89.

6 Arts. 258-260 of the Treaty on the Functioning of the European Union.

7 Halmai (2018) 10, 15.

8 Mangiameli and Saputelli (2013) 349-74.

9 The Proposal of the European Commission for a Council decision on the determination of a clear risk of a serious breach by the Republic of Poland of the rule of law [2017] COM 835 final.

10 The European Parliament resolution on a proposal calling on the Council to determine, pursuant to Article 7(1) of the Treaty on European Union, the existence of a clear risk of a serious breach by Hungary of the values on which the Union is founded [2018] P8_TA-PROV(2018)03 40.

11 Michelot (2017) link 1.

12 In this sense, see for example The 2018 EU Justice Scoreboard [2018] Communication from the Commission to the European Parliament, the Council, the European Central Bank, the European Economic and Social Committee and the Committee of the Regions COM 364 final, Šelih, Bond and Dolan (2017). 
with Art. 7(1) TEU submitted to the Council. The author then analyses the simultaneously forming body of CJEU case-law on the European Arrest Warrant (LM/ML), Asylum Procedures Directive (Torubarov), and the reform of the Polish Supreme Court and Ordinary Courts. The concluding part of the paper contains the author's final remarks on the deriving challenges for the Rule of Law concept implementation in the EU's autonomous legal order, in view of the approach adopted by the Commission, Parliament and the CJEU.

\section{THE CONCEPT OF RULE OF LAW IN THE EUROPEAN UNION}

The Rule of Law is often defined as a constitutional principle of the EU, ${ }^{13}$ occupying a central place among the EU's common values enshrined in Art. 2 and Art. 6 TEU, as well as in the Charter of Fundamental Rights of the European Union (CFREU). The stability of institutions guaranteeing democracy, the rule of law, Human Rights and respect for and protection of minorities remain the key eligibility conditions for a state's accession to the Union (Art. 49 TEU, the Copenhagen criteria). ${ }^{14}$ The main tool used to enforce these values is the EU Acquis chapter system;" ${ }^{15}$ the special emphasis of Chapters 23 ('Judiciary and fundamental rights') and 24 ('Justice, freedom and security') in the current round of access negotiations demonstrates the EU's growing awareness of the Rule of Law issues which could potentially arise in new Member States' national legal systems. ${ }^{16}$

The key components of this umbrella concept were gradually incorporated in the EU legal order by the CJEU, thus making the conduct of the EU's institutions and/or the Member States' authorities acting within the scope of European Law subject to procedural and substantive limitations. ${ }^{17}$ The sui generis nature of the EU's autonomous legal order defined the CJEU's legal reasoning: the Court seemed to have transposed the core components of the classic Montesquieu/Rechtsstaat theories whilst simultaneously considering the EU-specific rationales and legal machinery. ${ }^{18}$ With time, the CJEU elaborated the concept of the Rule of Law comprising such elements as the access to justice and judicial review, legal certainty, proportionality, equality and non-discrimination and transparency ${ }^{19}$ in order to guarantee the effective judicial protection of the EU individual, ${ }^{20}$ as well as the effectiveness of EU Law within national legal systems of the EU Member States. $^{21}$

13 Pech (2010) 359.

${ }^{14}$ Famous eligibility conditions have been developed by the European Council in the so-called Copenhagen Criteria (1993): (1) the political criteria - the stability of institutions guaranteeing democracy, the rule of law, Human Rights and respect for and protection of minorities, (2) the economic criteria - ability to face up to the pressure of the European Union market and competition and (3) the institutional criteria - an ability to take on the obligations of membership, including the capacity to effectively implement the rules, standards and policies that make up the body of EU law (the acquis'), and adherence to the aims of political, economic and monetary union.

15 In this sense, see for example Hillion (2016) 59-81; Sadurski (2016) 123-41; Gateva (2015) $7-37$.

16 Hillion (2013) 5-7.

17 Schroeder (2016) 5-9.

18 Pech (2009) 32-40.

19 Von Danwitz (2014) 1314-16.

20 Reich (2005) 112-15.

21 Prechal / Widdershoven (2011) 39-40. 
In accordance with the current Treaty framework, the EU has two key legal options to verify and remedy the arising Rule of Law violations in the Member States.

1. The Commission has the power to launch infringement proceedings on the basis of Arts. 258-260 of the Treaty on the Functioning of the European Union (TFEU) against any Member State that fails to comply with EU Law. If necessary, the matter may be referred to the CJEU so financial sanctions can be imposed. Infringement procedures remain the key supervisory mechanism of the Treaties but the Commission primarily aims at a correct and timely transposition of EU legislation into national legislation. ${ }^{22}$ Thus it seems reluctant to fully protect fundamental rights, concentrating on less sensitive technical issues of the internal market. ${ }^{23}$

2. The 'nuclear option' 24 of Art. 7 TEU was specifically included in the EU primary law as a mean to guarantee that any Member State respects not only the Treaty provisions as such, but also the common values captured in Art. 2 TEU - including the compliance with the Rule of Law principle. ${ }^{25}$ Art. 7 TEU comprises the preventive (Art. 7(1) determining a clear risk of a breach) and the sanctioning arms (Art. 7(2) - a serious and persistent breach of the common EU's values by a Member State). ${ }^{26}$ Art. 7(1) TEU allows the Council (of the EU) to invoke the preventive mechanism at the request of the European Parliament, one third of the Member States or of the European Commission. The Council then has to make a final decision by a majority of four fifths of its members, after obtaining the consent of the European Parliament. ${ }^{27}$

The sanctioning limb is more difficult to activate, considering the gravity of political and legal consequences of this measure. Art. 7(2) TEU provides that it is for the European Council to determine the existence of a serious and persistent breach by a Member State of the common EU's values, acting on a proposal by one third of the Member States or by the Commission and after obtaining the consent of the European Parliament. Importantly, the decision on the existence of a breach requires unanimity among the EU heads of state and governments, thus each Member State (except for the State concerned by the procedure) has a veto right on such a determination. ${ }^{28}$

The Treaties do not specify a sanction if the preventive mechanism has been invoked but Art. 7(3) TEU states that the final decision on activating the sanctioning arm may lead to the suspension of certain rights of the Member State concerned, including its voting rights in the Council. ${ }^{29}$ States having no respect to the EU key principles would be exempted from influencing the EU decision-making process. ${ }^{30}$ The Art. 7 TEU procedure is often defined as the safeguard clause of the whole EU legal system and is a remedy for an extraordinary situation, determined by assessing the compatibility of a Member State's conduct with the core principles of the EU's legal order. ${ }^{31}$ As argued by Hillion, the

22 Art. 17(1) of the Treaty on European Union.

23 Von Bogdandy et al (2012) link 2.

24 Barroso (2012).

25 Blanke and Mangiameli (2013) 349-55.

26 Bárd (2017) link 3.

27 Art. 7(1) of the Treaty on European Union (TEU), Consolidated version of the Treaty on European Union [2012] OJ C 326.

28 Art. 7(2) TEU; De Schutter, (2017) link 4.

29 Art. 7(3) TEU.

30 Blanke and Mangiameli (2013) 367.

31 Blanke and Mangiameli (2013) 354. 
distinctive feature of Arts. 7(1)-(2) TEU is also the scope of their application:'in the case of the infringement procedure, the failure is more limited and circumstantial, whereas in the context of Art. 7 TEU, the breach becomes systematic'. ${ }^{32}$ Hence, the mechanism is not confined only to situations where Member States implement EU Law. ${ }^{33}$ Although there is still no EU's institutional practice on the matter, the 'nuclear' option can arguably serve as a basis for more 'invasive' interventions than the traditional infringements procedure on the basis of TEU, TFEU or even CFREU provisions. ${ }^{34}$

Importantly, the EU Law guarantees are also complimented by the Council of Europe judicial (with the ECtHR as a main guardian of the ECHR proper implementation) and nonjudicial mechanisms of protection (such as the Venice Commission, Steering Committee for Human Rights, European Commission for the Efficiency of Justice etc). ${ }^{35}$ The Rule of Law checklist adopted by the Venice Commission presented the catalogue of the selected Human Rights benchmarks aimed at assessing the ECHR signatories' compliance with the latter principle - thus providing additional guidance for the EU and the EU Member States. The criteria developed within the EU and the CoE regimes overlap to a significant extent, as the Venice Commission provides a non-exhaustive list of basic guarantees comprising the principles of legality, ${ }^{36}$ legal certainty, ${ }^{37}$ prevention of abuse (misuse) of powers, ${ }^{38}$ equality before the law and non-discrimination ${ }^{39}$ and access to justice. ${ }^{40}$

Moreover, the EU Court of Justice frequently relied on the jurisprudence of the European Court of Human Rights while providing an interpretation to the abovementioned rights and principles, as all of the EU Member States simultaneously remained the ECHR signatories $^{41}$ and the majority of the CFREU rights correspond to the ones stemming from the Convention. ${ }^{42}$ The horizontal clauses of Arts. 51-53 of the Charter are specifically drafted to guarantee that the meaning and scope of the rights within the EU's legal order are equivalent to those laid down by said Convention. ${ }^{43}$ Art. 51 CFREU has become one of the main provisions guaranteeing effective realisation of rights stemming from EU Law within the national legal systems, ${ }^{44}$ especially when considering the rapid post-Lisbon development of the EU's Human Rights' acquis with the EU Charter of Fundamental Rights as a main frame of reference.

This can also be seen as one of the ways to enforce the Rule of Law principle in cases of the EU Member States governments misconduct. ${ }^{45}$ In particular, the first paragraph clarifies that '...the provisions of this Charter are addressed ... to the Member States only

32 Hillion (2016) 73.

33 Hillion (2016) 65.

34 Hillion (2016) 66.

35 In this sense, see for example Hoffmann-Riem (2014) 579-97.

36 Hoffmann-Riem (2014) section A.

37 Hoffmann-Riem (2014) section B.

38 Hoffmann-Riem (2014) section C.

39 Hoffmann-Riem (2014) section D.

40 Hoffmann-Riem (2014) section E.

41 Christoffersen (2009) 342.

42 Ferraro and Carmona, (2015) link 5.

43 Ahmed (2014) 118.

44 Jakab (2016) 187, 190.

45 Jakab (2016) 190. 
when they are implementing Union law'. ${ }^{46}$ Even though the broad scope of the Charter application did not stem directly from the text of Art. 51 or pertinent explanations, ${ }^{47}$ the CJEU proposed this interpretation in the Fransson case. ${ }^{48}$ In Fransson, the CJEU prominently stated that '...since the fundamental rights guaranteed by the Charter must [...] be complied with where national legislation falls within the scope of [EU] law, situations cannot exist which are covered in that way by [EU] law without those fundamental rights being applicable'. ${ }^{49}$ Thus, the CFREU rights are to be applicable not only when a Member State implements EU Law in the sense of applying it within its national legal system, but also when the Member State is seeking to derogate from EU Law ${ }^{50}$ - in this case, even an indirect connection to the Union law is considered sufficient. ${ }^{51}$

It should be mentioned that the CJEU prominently held, in the earlier Zambrano case, that Art. 20 TFEU precludes national measures which have the effect of depriving citizens of the Union of the genuine enjoyment of the substance of the rights conferred by virtue of their status as citizens of the Union'. ${ }^{52}$ The Fransson formula read in conjunction with the Zambrano fuelled the discussion on its far-reaching implications for the realisation of the Rule of Law principle as a part of the EU values'. ${ }^{53}$ The 'Reverse Solange' doctrine suggests that the EU Charter could also be applicable in case of systemic violations of Art. 2 TEU within the Member States's domestic legal system - maybe even outside the scope of EU Law, as the Union citizenship must entail a guarantee of last resort for fundamental rights in these cases. ${ }^{54}$ The ongoing systemic violations of EU Fundamental Rights in some EU Member States e.g., the Roma crisis in France, ${ }^{55}$ the corruption issues in Romania and Bulgaria ${ }^{56}$ the Hungarian constitutional reform, ${ }^{57}$ has intensified a discussion on the scope of application of the Art. 7 TEU procedure.

The European Commission's Rule of Law Framework (ROFL) was adopted in an attempt to strengthen the EU's response to these abuses, within the context of the multilevel system of Human Rights protection within the European Union (the EU, the Council of Europe, and the EU Member States). This framework is supposed to be complementary to Art. $7 \mathrm{TEU}$ and the formal infringement procedure under Art. $258 \mathrm{TFEU}$, which the Commission can launch if a EU Member State fails to implement a solution to clarify and correct the suspected violation of EU Law. ${ }^{58}$ The Commission seems to have provided a rather comprehensive definition of the Rule of Law principle, heavily relying both on the previous CJEU's and the ECtHR's case-law and demonstrating the EU's adherence to

46 Art. 51(1) of the Charter of Fundamental Rights of the European Union [2012] OJ C 326.

47 Explanatory note concerning Article 51, Explanations relating to the Charter of Fundamental Rights [2007] OJ C303/17.

48 Case C-617/10, Aklagaren. v. Hans Akerberg Fransson [2013] ECLI:EU:C:2013:105.

49 Case C-617/10, Aklagaren. v. Hans Åkerberg Fransson [2013] ECLI:EU:C:2013:105, para. 21.

50 Rauchegger (2015) 97, 108.

51 Hamuák (2016) 35.

52 Case C-34/09, Gerardo Ruiz Zambrano v Office national de l'emploi (ONEm) [2011] ECLI:EU:C:2011:124, para. 42.

53 Von Bogdandy and Spieker (2019).

54 In this sense, see for example Von Bogdandy et al (2012) 489-519; Von Bogdandy, Antpöhler and Ioannidis, (2017); Jakab (2016) 192-94.

55 O'Cinneide (2013) 122.

56 Spendzharova and Vachudova (2014) 157-59.

57 Gárdos-Orosz (2018) 94, 95-97.

58 Besselink (2017). 
reaching the Council of Europe objectives. ${ }^{59}$ The ROFL elaborated on such key components of the Rule of Law in the EU as the general principles of legal certainty, which requires amongst other things that legal norms are clear and predictable and may not be changed retrospectively; prohibition of arbitrariness of the executive powers guaranteeing that every EU or Member State intervention has a legal basis and is constrained by law; equality before the law, stemming from Arts. 20 and 21 of the EU Charter of Fundamental Rights. ${ }^{60}$

Special emphasis was also put on the principles of legality i.e., a transparent, accountable, democratic and pluralistic process for enacting laws, and the independence of the judiciary as they remain a guarantee of effective judicial review, including respect for fundamental rights and thus, from the broader perspective, are a prerequisite for upholding all rights and obligations deriving from the Treaties within national legal systems. ${ }^{61}$ Moreover, the ROFL elaborated on the institutional dimension of the Rule of Law concept by introducing an early warning mechanism aimed at addressing the systemic violations of fundamental rights by the EU Member States which create the clear risk of a serious breach of the EU's common values (Art. 2 TEU). ${ }^{62}$ A three-stage procedure precedes invoking Art. $7 \mathrm{TEU}$, and, in principle, instigates national governments to solve the internal issues to make the application of the nuclear option unnecessary.

The first stage is the Commission's assessment, during which the Commission collects and examines all relevant information pertaining to the situation and assesses whether a systemic threat to the rule of law exists. The second stage, unless the matter has already been satisfactorily resolved, involves the Commission issuing a rule of law recommendation addressed at the Member State, in order to fix the identified problems within a determined time limit. The third stage monitors the Member States' follow-up on the recommendations: if there is no satisfactory follow-up within the time limit set, the Commission can resort to one of the mechanisms set out in Art. 7 TEU. ${ }^{63}$

Considering the EU's efforts in drafting the ROFL, it could be argued that the possibility of invoking Art. 7 TEU has long been perceived as merely hypothetical. ${ }^{64}$ As argued by Halmai, evidence to support this point of view is the fact that the EU heavily relied on the infringement proceedings of Art. 258 TFEU as a tool to push the EU Member States' governments to solve pressing Rule of Law issues. ${ }^{65}$ However, Poland had been on the Commission's radar for almost three years concerning its controversial reforms regarding the functioning of the Polish Constitutional Tribunal and the appointment of its judges, with investigations under the new Rule of Law Framework having started in January

59 Communication from the Commission to European Parliament and Council - A new EU Framework to strengthen the Rule of Law (ROFL) [2014] COM/2014/0158 final, 3.

60 Communication from the Commission to European Parliament and Council - A new EU Framework to strengthen the Rule of Law (ROFL) [2014] COM/2014/0158 final 3-4, and Annex I 'The Rule of law as a foundational principle of the Union'.

${ }^{61}$ Communication from the Commission to European Parliament and Council - A new EU Framework to strengthen the Rule of Law (ROFL) [2014] COM/2014/0158 final 4.

62 Communication from the Commission to European Parliament and Council - A new EU Framework to strengthen the Rule of Law (ROFL) [2014] COM/2014/0158 final 6.

${ }^{63}$ Communication from the Commission to European Parliament and Council - A new EU Framework to strengthen the Rule of Law (ROFL) [2014] COM/2014/0158 final 7-9.

${ }^{64}$ In this sense, see for example Taborowski (2018) 238-39; Eppler/Hackhofer/Maurer (2018)

75-79; Šišková (2016) 805-13.

65 Halmai (2018) 3. 
2016. The Hungarian government had been heavily criticised from 2011 on, when the new constitution was adopted and a series of following legal and political changes led to the violation of the independence of the judiciary, freedom of expression, rights of migrants and refugees, corruption, and the rights of minorities. ${ }^{66}$

The ongoing EU's dialogue with the Hungarian and Polish governments, as well as the numerous infringement proceedings aimed at addressing the abovementioned challenges proved to be ineffective ${ }^{67}$ as the European Commission (Poland) and the Parliament (Hungary) were forced to submit the reasoned proposals calling on the Council to determine, pursuant to Art. 7(1) TEU, the existence of a clear risk of a serious breach by Poland and Hungary of the values on which the Union is founded. The CJEU's case-law $(L M / M L$, Torubarov lines of reasoning, as well as Polish judgements on the judicial system reform) seems to carefully approach the Rule of Law concept as well, in order to create the framework for the Article 7 TEU mechanism application in the future. It will be submitted that, due to the exceptional circumstances of these cases - namely invoking Art. 7 TEU for the first time in history, the legal reasoning adopted by the Commission, Parliament and the CJEU is crucial regardless of the Council's yes/no decision(s) in the cases at hand. Generally speaking, the EU's rhetoric on Poland and Hungary is likely to demonstrate if the Rule of Law concept can address effectively the threats to the EU's core values from the Member States' conduct - on the current stage of the Union's legal integration.

\section{ART. 7 TEU VS. POLAND AND HUNGARY: DOES LEGAL REASONING MATTER?}

The independence of the judiciary is considered one of the key elements of the EU's Rule of Law principle, in view of its importance for the effective judicial protection of the EU's individual, as well as the proper enforcement of the EU Law provisions within national legal systems. The Venice Commission Opinion no. 663/2012 on the independence of the judiciary, as regulated by Act CLXII of 2011, regarding the lowering of the retirement age for Hungarian judges to 62 years and subsequent decision of the Hungarian Constitutional Court declaring these changes unconstitutional resulted in the Commission lodging an infringement procedure on the basis of Art. 258 TFEU.

In Commission v Hungary, the CJEU carefully avoided a single mention of the judicial independence notion in the judgement. At this point, the Court preferred to address the issue through the lens of non-discrimination at the workplace, however establishing the violation of Arts. 2 and 6(1) of Directive 2000/78 (Employment Equality Framework Directive) due to the disproportionate and unjustified discrimination on grounds of age. ${ }^{68}$ The ROFL Framework mechanism was not applied despite these worrying signs as well as other indications of the Rule of Law violations by the Fidesz government. This is a clear difference from the Polish case where, in the course of the dialogue with the Polish government within the framework of the ROFL three-stage procedure, the Commission

66 The European Parliament resolution on a proposal calling on the Council to determine, pursuant to Article 7(1) of the Treaty on European Union, the existence of a clear risk of a serious breach by Hungary of the values on which the Union is founded [2018] P8_TA-PROV(2018)0340, paras. 51-61.

67 In this sense, see Pech and Wachowiec (2019) link 6.

68 Case C-286/12, Commission v. Hungary [2012] ECLI:EU:C:2012:687, paras. 74-81. 
adopted four Recommendations between July 2016 and December $2017 .{ }^{69}$ The main points of critique were

(1) the election procedure of the Polish Constitutional Tribunal judges,

(2) the independence of the judiciary in view of the laws on the Supreme Court, on the National Council for the Judiciary and on Ordinary Courts Organisation,

(3) the overall compliance of the ongoing judicial reform with common European standards and guarantees of judicial independence, including the Council of Europe benchmarks.

The CJEU also demonstrated its growing awareness of worrying developments in Associação Sindical dos Juizes Portugueses (ASJP) concerning the austerity measures leading to pay cuts for civil servants, including the judiciary. One of the first attempts was made to invoke Art. 2 TEU (the EU's values) in light of the EU Member States' obligation to guarantee and respect the independence of their national courts and tribunals. ${ }^{70}$ The judgment prominently elaborated on Art. 19 TEU, read in light of Art. 47 of the Charter of Fundamental Rights of the European Union, to demonstrate that the organisation of the national judiciary falling within the scope of EU Law in general, and Art. 2 TEU in particular, irrespective of whether the Member States are implementing Union law within the meaning of Art. 51(1) CFREU in this case. ${ }^{71}$ In order to justify this intervention and the development of the EU-specific principle of effective judicial review, ${ }^{72}$ the Court referred to the EU Member States courts competence to apply and/or interpret European Law, and the deriving right (or duty) to submit the requests for the CJEU's preliminary rulings (Art. 267 TFEU). ${ }^{73}$

The ASJP outcome shall however be seen in view of the ongoing EU's dialogue with the Polish and Hungarian governments. The ROFL Framework application did not have fruitful results in the Polish case and led to the ultimate Union's attempts to trigger a 'nuclear' Art. 7 TEU procedure. On 20 December 2017, due to the alleged violations of the principle of judicial independence by the Polish government, the Commission activated the Art. 7(1) TEU, (clear risk of a serious breach of the EU's values) procedure for the first time, and submitted a Reasoned Proposal for a Decision of the Council on the determination of a clear risk of a serious breach of the Rule of Law by Poland in light of the ongoing reform of the national judicial system. On 12 September 2018, the European Parliament voted in favour of launching Art. 7(1) TEU proceedings against the Hungarian government

${ }^{69}$ Commission Recommendation (EU) 2016/1374 of 27 July 2016 regarding the rule of law in Poland [2016] OJ L 217; Commission Recommendation (EU) 2017/146 of 21 December 2016 regarding the rule of law in Poland complementary to Recommendation (EU) 2017/146 [2017] OJ L 22; Commission Recommendation (EU) 2017/1520 of 26 July 2017 regarding the rule of law in Poland complementary to Recommendation (EU) 2016/1374 and (EU) 2017/146 [2017] OJ L 228; Commission Recommendation (EU) 2018/103 of 20 December 2017 regarding the rule of law in Poland complementary to Recommendations (EU) 2016/1374, (EU) 2017/146 and (EU) 2017/1520 [2018] OJ L 17.

70 Case C-64/16, Associação Sindical dos Juizes Portugueses v Tribunal de Contas [2018] ECLI:EU:C:2018:117.

71 Case C-64/16, Associação Sindical dos Juizes Portugueses v Tribunal de Contas [2018] ECLI:EU:C:2018:117 para. 29.

72 Pech / Platon (2018) link 7.

73 Case C-64/16, Associação Sindical dos Juizes Portugueses v Tribunal de Contas [2018] ECLI:EU:C:2018:117, paras. 40-45. 
on the basis of a report prepared by MEP Judit Sargentini, listing multiple alleged inconsistencies of the Hungarian legislation with the EU's acquis.

Hungary promptly initiated the action for annulment of the European Parliament's resolution on the Art. 7 TEU proposal relying on four pleas in law. First, only the votes for and against were counted, excluding abstentions, which is contrary to Art. 354 TFEU and Art. 178(3) of the Rules of Procedure of the European Parliament. Secondly, the President of the European Parliament did not consult the European Parliament Committee on Constitutional Affairs in relation to the interpretation of the rules of procedure, despite that before the vote there had been justified doubts as to the method of counting expressed in the opinion of the European Parliament's Legal Service to the President of 7 September 2018.

Thirdly, the EU Parliament Members could not exercise their rights necessary for carrying out their duties of representing the people in accordance with the principle of democracy, which includes the possibility of abstention. Fourthly, the contested resolution infringes the principles of sincere cooperation (Art. 4(3) TEU), legitimate expectations and legal certainty, since the resolution contains statements which refer to infringement proceedings which have already been concluded or are still ongoing. ${ }^{74}$ The case is pending at time of writing, however, the CJEU has touched upon the two first pleas in the recent Order of 14 May 2019 - the opinion of the European Parliament's Legal Service of September 7, 2018 was removed from the file. According to the Court, even though the opinion in question was arguably obtained from the website, ${ }^{75}$ the disclosure of this document had not been authorized by the Parliament. ${ }^{76}$ Hence, the recourse to the opinion in question would run counter to the requirements of a fair trial and would amount to circumventing the procedure for requesting access to such a document in accordance with Regulation No. 1049/2001 regarding public access to European Parliament, Council and Commission documents (Transparency Regulation). ${ }^{77}$

The final outcome of Hungary $v$ European Parliament is still unknown (at the time of writing). However, if the European Parliament's resolution from 12 September 2018 will be retained, it is for the Council to determine whether there is a clear risk of a serious breach by both Member States of the common EU's values referred to in Art. 2 TEU such as the rule of law and respect for human rights. ${ }^{78}$ As argued by Bard and Carrera, the provisions of Art. 7 set a very high threshold inside the Council in order to activate the procedure: a fourfifths majority is needed to invoke the preventive arm, whereas the sanctioning arm can be vetoed by any EU Member State. ${ }^{79}$ However, regardless of the Council yes/no decisions in the Polish and Hungarian cases, the submissions of the Commission and the Parliament are likely to have a significant impact on the development of the Rule of Law concept in EU Law.

${ }^{74}$ Case C-650/18, Hungary v Parliament (action brought on 17 October 2018).

75 Case C-650/18, Hungary v Parliament (action brought on 17 October 2018). Order from 14 May 2019, para. 17.

76 Case C-650/18, Hungary v Parliament (action brought on 17 October 2018). Order from 14 May 2019, paras. 8-9.

77 Case C-650/18, Hungary v Parliament (action brought on 17 October 2018). Order from 14 May 2019, paras. 10-14.

78 Art. 7(1) TEU.

79 Carrera and Bárd (2018) link 8. 
The legal reasoning of the proposals does not seem completely coherent as the Commission's reasoning (Poland) is rather well founded, while the Parliament's argumentation (Hungary) seems incomparably less convincing and more policy-oriented. Moreover, the view taken by the Parliament in its attempt to trigger Art. 7 TEU questions the substance of the Rule of Law concept in the EU by adding the components of purely socio-economic nature to the latter notion, which was always interpreted primarily in the shadow of the Council of Europe (ECHR-based) benchmarks, even though considering the EU's objectives and legal machinery. ${ }^{80}$

For instance, the Commission's analysis of the Polish case elaborates on

(a) the lack of an independent and legitimate constitutional review,

(b) the threats to the independence of the ordinary judiciary.

While discussing the Constitutional Tribunal reform, the Commission demonstrates its adherence to the comprehensive overview of pertinent Polish legislation offered by ROFL Recommendations (EU) 2016/1374, (EU) 2017/146 and (EU) 2017/1520. ${ }^{81}$ The issue of independence of ordinary judges is discussed in detail as well, with special emphasis on Art. 6(1) ECHR, as interpreted by the ECtHR's case-law (Campbell, Urban, Fruni lines of reasoning), the $2010 \mathrm{CoE}$ Recommendation and by the Reports of the European Commission for Democracy through Law ('Venice Commission') previously made on the Polish reform of judiciary. ${ }^{82}$

Regarding the content of the Parliament's proposal, the Sargentini report described a multiplicity of issues either in light of the Rule of Law concept e.g., the judiciary reform, ${ }^{83}$ the legislation on the constitutional and electoral systems, ${ }^{84}$ the right to equal treatment, ${ }^{85}$ the Human Rights of minorities, migrants, asylum seekers and refugees, ${ }^{86}$ or as closely

80 Von Danwitz (2014) 1320-21.

81 The Proposal of the European Commission for a Council decision on the determination of a clear risk of a serious breach by the Republic of Poland of the rule of law [2017] COM 835 final, paras. 26-39, 40-55, 56-90.

82 The Proposal of the European Commission for a Council decision on the determination of a clear risk of a serious breach by the Republic of Poland of the rule of law [2017] COM 835 final, paras. 94-96, 98, 116, 120-127, 132-136 etc.

83 The European Parliament resolution on a proposal calling on the Council to determine, pursuant to Article 7(1) of the Treaty on European Union, the existence of a clear risk of a serious breach by Hungary of the values on which the Union is founded [2018] P8_TA-PROV(2018)0340, paras. $12-19$.

${ }^{84}$ The European Parliament resolution on a proposal calling on the Council to determine, pursuant to Article 7(1) of the Treaty on European Union, the existence of a clear risk of a serious breach by Hungary of the values on which the Union is founded [2018] P8_TA-PROV(2018)0340, paras. $7-11$.

85 The European Parliament resolution on a proposal calling on the Council to determine, pursuant to Article 7(1) of the Treaty on European Union, the existence of a clear risk of a serious breach by Hungary of the values on which the Union is founded [2018] P8_TA-PROV(2018)0340, paras. 46-50.

${ }^{86}$ The European Parliament resolution on a proposal calling on the Council to determine, pursuant to Article 7(1) of the Treaty on European Union, the existence of a clear risk of a serious breach by Hungary of the values on which the Union is founded [2018] P8_TA-PROV(2018)0340, paras. 51-72. 
inter-connected and deriving ones e.g., corruption issues, ${ }^{87}$ privacy and data protection, ${ }^{88}$ freedom of expression, ${ }^{89}$ academic independence, ${ }^{90}$ freedom of religion and association, ${ }^{91}$ or the abolition of economic and social rights..$^{92}$ The report covers the cases that were closed several years ago since the violation has been arguably eliminated by the Hungarian government e.g., the reform of the laws on the retirement of judges in view of the CJEU's Case C-286/12, Commission v Hungary ${ }^{93}$ or the civil code reforms, in light of the ECtHR's Gaszó v Hungary, App. No. 48322/12. ${ }^{94}$

Moreover, the scope of the report also seems questionable in light of its purpose of triggering Art. 7 (1) TEU (i.e., violation of the EU Rule of Law principle or fundamental EU values). ${ }^{95}$ The references to the legislation on the conflicts of interest of the Hungarian Parliament members could serve as illustrative examples in this regard. The Sargentini report specifically elaborates on the tougher set of rules in the area of economic conflict of interest for the members of the Hungarian parliament - accompanied by a more robust obligation to submit asset declarations. ${ }^{96}$ The Parliament submissions also include an Economic and social rights section where the legislation allowing local authorities to punish

87 The European Parliament resolution on a proposal calling on the Council to determine, pursuant to Article 7(1) of the Treaty on European Union, the existence of a clear risk of a serious breach by Hungary of the values on which the Union is founded [2018] P8_TA-PROV(2018)0340, paras. 20-24.

${ }^{88}$ The European Parliament resolution on a proposal calling on the Council to determine, pursuant to Article 7(1) of the Treaty on European Union, the existence of a clear risk of a serious breach by Hungary of the values on which the Union is founded [2018] P8_TA-PROV(2018)0340, paras. 25-26.

${ }^{89}$ The European Parliament resolution on a proposal calling on the Council to determine, pursuant to Article 7(1) of the Treaty on European Union, the existence of a clear risk of a serious breach by Hungary of the values on which the Union is founded [2018] P8_TA-PROV(2018)0340, paras. 27-32.

90 The European Parliament resolution on a proposal calling on the Council to determine, pursuant to Article 7(1) of the Treaty on European Union, the existence of a clear risk of a serious breach by Hungary of the values on which the Union is founded [2018] P8_TA-PROV(2018)0340, paras. 33-36.

91 The European Parliament resolution on a proposal calling on the Council to determine, pursuant to Article 7(1) of the Treaty on European Union, the existence of a clear risk of a serious breach by Hungary of the values on which the Union is founded [2018] P8_TA-PROV(2018)0340, paras. $37-45$.

92 The European Parliament resolution on a proposal calling on the Council to determine, pursuant to Article 7(1) of the Treaty on European Union, the existence of a clear risk of a serious breach by Hungary of the values on which the Union is founded [2018] P8_TA-PROV(2018)0340., paras. $73-77$.

93 The European Parliament resolution on a proposal calling on the Council to determine, pursuant to Article 7(1) of the Treaty on European Union, the existence of a clear risk of a serious breach by Hungary of the values on which the Union is founded [2018] P8_TA-PROV(2018)0340, paras. 15.

94 The European Parliament resolution on a proposal calling on the Council to determine, pursuant to Article 7(1) of the Treaty on European Union, the existence of a clear risk of a serious breach by Hungary of the values on which the Union is founded [2018] P8_TA-PROV(2018)0340, paras. 16.

95 UJHELYI (2018) link 9.

96 UJHELYI (2018) link 9. 
homelessness or the child's rights were discussed in view of the UN Special Rapporteur on extreme poverty and human rights and the UN Working Group on discrimination against women in law and in practice reports. However there was no convincing analysis of current factual circumstances in light of these documents. ${ }^{97}$

Considering the significant differences in the approach taken by the European Commission and the Parliament in the Polish and Hungarian cases, as well as the socioeconomic components of the Sargentini report, one could possibly indicate another emerging issue - namely, a presumable ineffectiveness of the Rule of Law concept as a tool to address the multiplicity of challenges arising on the present stage of the EU's legal integration. The minority Opinion to the Parliament's report might serve as an additional evidence of this: elaboration on the attempts of the Hungarian government to resolve social problems was considered inconsistent with the final rationale of Art. 7 TEU mechanism, and thus leading to dividing the European Union and deepening its crisis. ${ }^{98}$

\section{THE RULE OF LAW BEYOND ART. 7 TEU - THE CJEU'S INTERVENTION}

Beyond the Commission's and the Parliament's proposals aiming to trigger Art. 7 TEU mechanism, the evolving body of the CJEU's jurisprudence with the Rule of Law component adds complexity to the overall picture. Recent European Arrest Warrant cases $\left(L M,{ }^{99} M L\right),{ }^{100}$ the ongoing proceedings concerning the reform of the Polish judicial system, ${ }^{101}$ or the request of the Hungarian court on the scope of the right to an effective remedy in the asylum procedures (Torubarov) ${ }^{102}$ can serve as the illustrative examples in this respect.

In $L M$ and $M L$, the Court attempted to clarify the borders of mutual trust between the judicial authorities of the EU Member States, in view of the systemic violations of the Art. 2 TEU values, including the Rule of Law principle. The contested provisions were Art. 1(3) of the European Arrest Warrant (EAW) Framework Decision aiming at ensuring the respect for fundamental rights and fundamental legal principles as enshrined in Article 6 [TEU] in course of the Warrant execution, and Arts. 3, 4 and 4a of Framework Decision 2002/584 which set out the grounds for mandatory or optional refusal of a European arrest warrant. These cases develop the earlier Aranyosi/Căldăraru line of reasoning, where the CJEU clarified that the refusal to execute the European Arrest Warrant required the two-stage test:

(a) determining the risk of breach of fundamental rights in general, due to general or systemic deficiencies in the remedies provided in the issuing Member State

(b) the risk-exposure of the individual concerned in the specific case. ${ }^{103}$

97 UJHELYI (2018) link 9.

98 Minority Opinion pursuant to Rule 52a(4) of the Rules of Procedure Marek Jurek, Beata Gosiewska, Mylène Troszczynski, Auke Zijlstra, Barbara Kappel.

99 Case C-216/18 PPU, Minister for Justice and Equality/ LM [2018] ECLI:EU:C:2018:586.

100 Case C-220/18 PPU, Generalstaatsanwaltschaft (Conditions de détention en Hongrie)/ ML [2018] ECLI:EU:C:2018:58.

101 Case C-619/18, European Commission v Republic of Poland (action brought on 2 October 2018).

102 Case C-556/17, Torubarov (Request for a preliminary ruling made on 22 September 2017).

103 Joined cases C-404/ 15 and C-659/15 PPU, Pal Aranyosi (C-404/15) and Robert Caldararu (C-659/15 PPU) [2016] ECLI:EU:C:2016:198, paras. 88-100. 
The $L M$ case creates a framework for the Aranyosi/Căldăraru test application in cases of the ongoing proceedings under Art. 7(1) TEU mechanism, and thus the presumable existence of the clear risk of a serious breach of the Rule of Law. The Irish Court submitted a request for a preliminary reference to the CJEU to clarify if the evidence on (a) the lack of an independent and legitimate constitutional review and (b) the threats to the independence of the ordinary judiciary documented by a number of international and European institutions and bodies, and mentioned by the Commission's report in the Polish case might be considered sufficient ground for non-execution of the European Arrest Warrant due to the alleged breach of the applicant's right of access to an independent and impartial tribunal guaranteed by Art. 47 CFREU. ${ }^{104}$

Advocate General Tanchev emphasised that the right to a fair trial, also stemming from corresponding Art. 6 of the European Convention, might be subject to limitations, unless these limitations are so severe that the essence of that right is violated. ${ }^{105}$ In the given circumstances, in order for the executing authority to postpone surrender, there must be a real risk not of a breach of the right to a fair trial but of 'a flagrant denial of justice'. In order to illustrate the practical applicability of this test, the Advocate General elaborated on the ECtHR's case-law establishing the Art. 6 ECHR breach regarding the independence of the courts (Al Nashiri line of reasoning). ${ }^{106}$

The CJEU preferred to skip these arguments and provided a very modest response, refusing to accept a clear risk of a serious breach of EU values i.e., Art. 7(1) TEU as a benchmark. ${ }^{107}$ Rather, the Court allowed for derogating from the mutual trust principle only in cases of activating the sanctioning arms of Arts. 7(2)-(3) (serious and persistent breach of the common EU's values) by the European Council - in order to invoke recital 10 EAW (Suspension of the Warrant) on the first stage of the Aranayosi test. ${ }^{108}$ Until such a decision is made, the executing court can derogate from executing the EAW on the basis of Art. 1(3) of the Framework Decision only in exceptional circumstances - if the supplementary information received from the issuing judicial authority allows to establish the existence of that risk for the individual concerned. ${ }^{109}$

The twin judgment in the $M L$ case confirms this premise, limiting the Aranyosi assessment of detention conditions in Hungary (the issuing Member State) to the first prisons in which the person concerned will be held immediately after the surrender on the basis of the European Arrest Warrant. ${ }^{110}$ The Court reaffirmed that mutual trust is one of the key principles of the EU legal order, stemming from a set of common values on which the Union is founded, as stated in Art. 2 TEU and that it can only cease to operate in exceptional

104 Case C-216/18 PPU, Minister for Justice and Equality/ LM [2018] ECLI:EU:C:2018:586, paras. 18-25.

105 Opinion of Advocate General Tanchev delivered on 28 June 2018. Case C-216/18 PPU, Minister for Justice and Equality/ LM [2018] ECLI:EU:C:2018:517, paras. 75-81.

106 Opinion of Advocate General Tanchev delivered on 28 June 2018. Case C-216/18 PPU, Minister for Justice and Equality/ LM [2018] ECLI:EU:C:2018:517, paras. 86-96.

107 Case C-216/18 PPU, Minister for Justice and Equality/ LM [2018] ECLI:EU:C:2018:586, paras. 61-69.

108 Case C-216/18 PPU, Minister for Justice and Equality/ LM [2018] ECLI:EU:C:2018:586, paras. $70-73$.

109 Case C-216/18 PPU, Minister for Justice and Equality/ LM [2018] ECLI:EU:C:2018:586, para. 77.

110 Case C-220/18 PPU, Generalstaatsanwaltschaft (Conditions de détention en Hongrie)/ ML [2018] ECLI:EU:C:2018:58, paras. 77-89. 
circumstances. ${ }^{111}$ However, the Court specifically mentioned that it is not going to rule on the existence of systemic or generalized deficiencies in detention conditions in the Hungarian prisons. ${ }^{12}$ Just like in the Aranyosi/Căldăraru cases, the CJEU left the core of the mutual trust concept in EU Law intact ${ }^{113}$ and therefore avoided granting national courts a realistic possibility to declare the Framework Decision invalid, for being in contrast with the EU's fundamental rights - at least on the basis of the ongoing investigations under Art. 7 TEU .114

It could be argued that solving the $L M$ and $M L$ cases was a complex task for the CJEU as it required the politically-neutral approach before the final decisions on Art. 7(1) TEU in the Polish and Hungarian case. This line of reasoning is also important in light of another issue of crucial importance, the effectiveness of judicial review in the asylum cases. Since 2015, the Hungarian courts can namely either uphold or annul but cannot change the decision of the asylum authority. Hence, the asylum procedures, and consequently, the unlawful detention in the transit zones, do not have a maximum time limit in practice. ${ }^{115}$ This is one of the sensitive issues mentioned by the Sargentini report. ${ }^{116}$ The Hungarian judges were reluctant to question the legitimacy of the national asylum legislation reform and continued to participate in their application - even though the ECtHR found some of the solutions to be contrary to International Law. ${ }^{117}$

The preliminary ruling request submitted by the Pécs City Administrative and Labour Court in the Torubarov case is de facto the first attempt to challenge this system substantively. The court asked to clarify if Art. 46 (3) Directive 2013/32 (Asylum Procedures Directive) in conjunction with Art. 47 CFREU (The right to a fair trial and an effective remedy) allows for Hungarian courts to amend administrative decisions of the competent asylum authority refusing international protection and also to grant such protection. ${ }^{118}$ Advocate General Bobek made a detailed reference to the recent Alheto case concerning the interpretation of Art. 46(3) of the Asylum Procedures Directive ${ }^{119}$ and reiterated the main findings of that judgment:

(a) Directive 2013/32 does not determine a particular way in which this provision should be implemented, and the EU Member States choose that decisions may be altered, or they can opt for cassation

(b) such a review must be a comprehensive, assessing both issues of law and fact. ${ }^{120}$

111 Case C-220/18 PPU, Generalstaatsanwaltschaft (Conditions de détention en Hongrie)/ML [2018] ECLI:EU:C:2018:58, paras. 46-50.

112 Case C-220/18 PPU, Generalstaatsanwaltschaft (Conditions de détention en Hongrie)/ML [2018] ECLI:EU:C:2018:58, paras. 67-71.

113 Gáspár-Szilágyi (2016) 215-16.

114 The European University Institute Centre For Judicial Cooperation (2016) link 10.

115 Nagy (2018) 48-50.

116 The European Parliament resolution on a proposal calling on the Council to determine, pursuant to Article 7(1) of the Treaty on European Union, the existence of a clear risk of a serious breach by Hungary of the values on which the Union is founded [2018] P8_TA-PROV(2018)0340, para. 66-72.

117 Ilias and Ahmed v. Hungary, App. No. 47287/15 (ECtHR, 14 March 2017).

118 Case C-556/17, Torubarov (Request for a preliminary ruling made on 22 September 2017).

119 Case C-585/16, Serin Alheto v Zamestnik-predsedatel na Darzhavna agentsia za bezhantsite [2018] ECLI:EU:C:2018:584.

120 Case C-556/17, Torubarov (Request for a preliminary ruling made on 22 September 2017). Opinion of Advocate General Bobek [2019] ECLI:EU:C:2019:335, paras. 39-47. 
Predictably, the Advocate General also addressed the question in light of the Rule of Law concept which was seen as the part of the wider constitutional and fundamental rights considerations that are of significance for the case ${ }^{121}$ - even though avoiding directly mentioning the ongoing Art. 7 TEU procedure. The Opinion de facto follows the logic of the Sargentini report, also considering the effectiveness of a judicial protection in the asylum cases (stemming from Art. 19(1) TEU and Art. 47 CFREU) through the prism of the systemic, structural rule of law concerns' ${ }^{122}$ In view of the crucial role of effective judicial review in preserving the Rule of Law in any legal system, this set of guarantees shall apply to any area of EU Law being implemented at the national level, including common procedures for granting and withdrawing international protection. ${ }^{123}$ Hence, the current Hungarian legislative framework arguably fails to meet the requirements of effective judicial review set out in Art. 46(3) of Directive 2013/32 and interpreted in the light of Art. 47(1) CFREU. ${ }^{124}$

The CJEU's Grand Chamber generally followed these suggestions but the cautionary reasoning of the Torubarov judgement makes a clear distinction from the far-reaching AG Opinion. This approach can be explained by the sensitive nature of the ongoing proceedings under Art. 7 TEU against the Hungarian government, as well as the special importance of the request, i.e., challenging the compatibility of the key component of the Hungarian asylum system, the appeal system, with EU Law. The judges prominently avoided to explore the conduct of the Hungarian immigration authorities through the prism of the systemic Rule of Law concerns. Rather, the question of the Pécs City Administrative and Labour Court was addressed from the perspective of the direct effect of EU Law in the asylum matters.

The CJEU focused on the analysis of rationales and wording of the Asylum Procedures Directive; referring to the above-mentioned Alheito, the Court emphasised that Art. 46(3) defines the scope of the right to an effective remedy by specifying that the EU Members States must ensure that the court before which the decision relating to the application for international protection is contested, carries out a full and ex nunc examination of both facts and points of law, including new facts and evidence. ${ }^{125}$ Moreover, even though Directive 2013/32 affords EU Member States some discretion in organising the appeal system in the asylum cases, the national implementing legislation shall comply with the principle of effective judicial protection which is enshrined in Art. 47 CFREU $^{126}$ and constitutes the very essence of EU law. ${ }^{127}$ Hence, Art. 46(3) of Directive 2013/32 would be deprived of any practical effect if it were accepted that, after delivery of a judgment in which the court conducted, in accordance with that provision, a comprehensive assessment of the application for international protection of the applicant, the administrative body referred to in Art. 2(f)

121 Case C-556/17, Torubarov (Request for a preliminary ruling made on 22 September 2017). Opinion of Advocate General Bobek [2019] ECLI:EU:C:2019:335, para. 38.

122 Case C-556/17, Torubarov (Request for a preliminary ruling made on 22 September 2017). Opinion of Advocate General Bobek [2019] ECLI:EU:C:2019:335, para. 58.

123 Case C-556/17, Torubarov (Request for a preliminary ruling made on 22 September 2017). Opinion of Advocate General Bobek [2019] ECLI:EU:C:2019:335, para. 125.

124 Case C-556/17, Torubarov (Request for a preliminary ruling made on 22 September 2017).

Opinion of Advocate General Bobek [2019] ECLI:EU:C:2019:335, para. 126.

125 Case C-556/17, Torubarov [2019] ECLI:EU:C:2019:626, para. 51.

126 Case C-556/17, Torubarov [2019] ECLI:EU:C:2019:626, para. 55

127 Case C-556/17, Torubarov [2019] ECLI:EU:C:2019:626, para. 73. 
of Directive 2013/32 (determining authority) could take a decision that ran counter to that assessment. ${ }^{128}$

In view of these considerations, the CJEU prominently declared that, under the circumstances of the case, the courts shall have the power to overturn administrative decisions in granting of international protection disapplying - if necessary - the national law that would prohibit them from proceeding in that way. ${ }^{129}$ It could be said that the CJEU elaborated substantively on the right to an effective remedy before a court or tribunal (Art. 47 CFREU) 'as shield against the national governments limitation of judicial reformatory powers', thus opening the floor for new claims within the context of asylum and immigration adjudication, even though not directly referring to the Art. 7(1) TEU procedure. ${ }^{130}$

The ongoing infringement proceedings on the Law on Ordinary Courts ${ }^{131}$ concerning the establishment of different retirement ages for female and male judges in Poland, which the Commission finds to be contrary to Art. 157 TFEU and Directive 2006/54 ('Gender Equality Directive') and on the Law on the Supreme Court ${ }^{132}$ regarding Polish legislation on lowering of the retirement age for Supreme Court judges, as well as the pending request for a preliminary ruling on national measures establishing the Disciplinary Chamber of the Supreme Court ${ }^{133}$ do not add consistency to the Rule of Law principle interpretation or application either.

On 24 June 2019, the CJEU released the first judgement in this series of the Rule of Law cases regarding the ongoing reform of the Polish judicial system. ${ }^{134}$ Arts. 37 and 111 of the New Law on the Supreme Court lowered the mandatory retirement age for Supreme Court judges - including those in office - from 70 to 65 and provided the President of the Republic with a discretion to extend the judges mandate beyond the newly established retirement age. ${ }^{135}$ Heavily relying on the earlier $A S J P / L M$ judgements, the Commission stated that these measures failed to meet the requirement of judicial independence, which remains a key component of the fundamental right to a fair trial stemming from combined reading of Art. 19(1) TEU and Art. 47 CFREU. ${ }^{136}$ The Republic of Poland argued that the infringement proceedings should be discontinued as all national provisions challenged by the Commission in its action have been repealed, and their effects eliminated, by the Law amending the New Law on the Supreme Court of 21 November 2018. ${ }^{137}$

128 Case C-556/17, Torubarov [2019] ECLI:EU:C:2019:626, paras. 58, 76.

129 Case C-556/17, Torubarov [2019] ECLI:EU:C:2019:626, paras. 73-79.

130 Moraru / Strazzari / Penasca (2017) link 11.

131 Case C-192/18, European Commission v Republic of Poland (action brought on 15 March 2018).

132 Case C-619/18, European Commission v Republic of Poland (action brought on 2 October 2018).

133 Joined Cases C585/18, C624/18 and C625/18, A.K. (C585/18) v Krajowa Rada Sadownictwa and CP (C624/18), DO (C625/18) v Sąd Najwyższy (C624/18 and C625/18), joined party Prokurator Generalny zastępowany przez Prokurature Krajowa (Request for a preliminary ruling from the Sąd Najwyższy (Poland) lodged on 20 September 2018).

${ }^{134}$ Case C619/18, Commission v Poland (Indépendance de la Cour suprême) [2019] ECLI:EU:C:2019:531.

135 Case C619/18, Commission v Poland (Indépendance de la Cour suprême) [2019]

ECLI:EU:C:2019:531, paras. 9-14.

136 Case C619/18, Commission v Poland (Indépendance de la Cour suprême) [2019]

ECLI:EU:C:2019:531, para. 1, 34.

137 Case C619/18, Commission v Poland (Indépendance de la Cour suprême) [2019]

ECLI:EU:C:2019:531, paras. 27-28. 
However, the CJEU found it necessary to elaborate on the Commission's submissions on the basis of the position in which the Member State at issue found itself at the end of the period laid down in the reasoned opinion, in accordance with the previously settled caselaw. ${ }^{138}$ Following the AG Tanchev Opinion, the CJEU declared the national legislation incompatible with Art. 19(1) TEU, which obliges the EU Member States to provide remedies sufficient to ensure effective legal protection in the fields covered by Union law. ${ }^{139}$ The legal reasoning of the Court presents a special interest in this regard.

First, the national courts are defined as the guarantors of proper realization of the Art. 2 TEU values, including the rule of law, in the EU Member States. ${ }^{140}$

Secondly, the CJEU seems to have further developed the ASJP approach by adding an additional step in assessment of the possible limitations to the judicial independence: ${ }^{141}$ 'given that these national measures are justified and proportionate, they shall not affect the imperviousness of the court concerned to external factors and its neutrality with respect to the interests before it'. ${ }^{142}$

Thirdly, in light of the 'Reverse Solange' concerns of the Polish and Hungarian governments, the Court emphasized that the material scope of Art. 19(1) TEU refers to the fields covered by Union law - irrespective of whether the Member States are implementing Union law within the meaning of Art. 51(1) of the EU Charter. ${ }^{143}$

Thus, even though Art. 51(1) CFREU does not extend the scope of application of EU Law beyond the European Union's competences, the EU Member States shall ensure that the organisation and functioning of the bodies which, courts or tribunals within the meaning of EU Law, ${ }^{144}$ meet the requirements stemming from the EU-specific principle of effective judicial review, including the guarantees of judicial independence. ${ }^{145}$ The key rationales for this choice is the special role of the national courts in the EU Law enforcement:

(a) ensuring the legal protection which citizens derive from the direct effect of the Union Law through the duty of consistent interpretation ${ }^{146}$

(b) participation in judicial dialogue with the EU Court of Justice through the preliminary ruling procedure (Art. 267 TFEU). ${ }^{147}$

The expected judgements in two other Polish cases concerning the ongoing judicial reform were also considered capable of limiting the EU Member States discretion as to the

138 Case C619/18, Commission v Poland (Indépendance de la Cour suprême) [2019] ECLI:EU:C:2019:531, paras. 30-31.

139 Case C619/18, Commission v Poland (Indépendance de la Cour suprême) [2019] ECLI:EU:C:2019:531, para. 126.

140 Case C619/18, Commission v Poland (Indépendance de la Cour suprême) [2019] ECLI:EU:C:2019:531, paras. 42-44.

141 Simonelli (2019 link 12.

142 Case C619/18, Commission v Poland (Indépendance de la Cour suprême) [2019] ECLI:EU:C:2019:531, para. 79.

143 Case C619/18, Commission v Poland (Indépendance de la Cour suprême) [2019]

ECLI:EU:C:2019:531, paras. 50-52.

${ }^{144}$ Case C619/18, Commission v Poland (Indépendance de la Cour suprême) [2019]

ECLI:EU:C:2019:531, paras. 53-57.

145 Case C619/18, Commission v Poland (Indépendance de la Cour suprême) [2019]

ECLI:EU:C:2019:531, paras. 58-59.

146 Case C619/18, Commission v Poland (Indépendance de la Cour suprême) [2019]

ECLI:EU:C:2019:531, paras. 42-44.

147 Case C619/18, Commission v Poland (Indépendance de la Cour suprême) [2019]

ECLI:EU:C:2019:531, para. 45. 
organisation of their judiciaries. ${ }^{148}$ The same AG (Evgeni Tanchev) was appointed to pave the way for the Court's analysis, hence the strongly related reasoning of both Opinions and them being rather similar to already adopted Opinion in the Law on the Supreme Court case. ${ }^{149}$ Special emphasis is put on the context of the Polish justice system reform instituted by measures adopted in 2017, which had already been the subject of the Commission's reasoned proposal in accordance with Art. 7(1) TEU regarding the rule of law in Poland. According to Advocate General Tanchev, Art. 19(1) TEU shall be seen as a concrete manifestation of respect for the rule of law under Art. 2 TEU, with Art. 47 CFREU specifying the content of the right to an independent and impartial tribunal previously established by law stemming from these provisions. ${ }^{150}$

After the detailed assessment of the scope of the above-mentioned guarantees and having considered pertinent case-law of the European Court of Human Rights, the Advocate General found that

(a) the new retirement rules for judges of the Polish ordinary courts are contrary to EU Law since the contested measures violate the prohibition of discrimination on grounds of sex and the principles of irremovability of judges and of judicial independence ${ }^{151}$

(b) the Disciplinary Chamber of the Polish Supreme Court does not offer sufficient guarantees of independence under EU Law - in light of involvement of the legislative authorities in electing the 15 judicial members of the National Council of the Judiciary, and the role of that body in selecting judges eligible for appointment by the President of the Republic of Poland to the Disciplinary Chamber of the Supreme Court. ${ }^{152}$

It could be argued that the most problematic issue of this line of reasoning is the gravity of the intervention in the traditional area of the procedural autonomy of the EU Member States ${ }^{153}$ on the basis of the EU-specific principle of effective judicial review which seems to be more predatory than the ASJP approach. Although a set of general rules to be observed while applying EU Law was established, ${ }^{154}$ the organisation, competence

148 In this sense, see for example Rosas (2019) link 13.

149 Case C-192/18, European Commission v Republic of Poland (action brought on 15 March 2018). Opinion of Advocate General Tanchev delivered on 20 June 2019, ECLI:EU:C:2019:529; Joined Cases C585/18, C624/18 and C625/18, A.K. (C585/18) v Krajowa Rada Sadownictwa and CP (C624/18), DO (C625/18) v Sąd Najwyższy (C624/18 and C625/18), joined party Prokurator Generalny zastepowany przez Prokurature Krajowa (Request for a preliminary ruling from the Sąd Najwyższy (Poland) lodged on 20 September 2018). Opinion of Advocate General Tanchev delivered on 27 June 2019, ECLI:EU:C:2019:551.

150 Case C-192/18, Opinion of Advocate General Tanchev delivered on 20 June 2019, ECLI:EU:C:2019:529, paras. 1-6; Joined Cases C585/18, C624/18 and C625/18, A.K. (C585/18) v Krajowa Rada Sąownictwa and CP (C624/18), DO (C625/18) v Są Najwyższy (C624/18 and C625/18), joined party Prokurator Generalny zastępowany przez Prokurature Krajowa, Opinion of Advocate General Tanchev delivered on 27 June 2019, ECLI:EU:C:2019:551, paras. 1-7.

151 Case C-192/18, Opinion of Advocate General Tanchev delivered on 20 June 2019, ECLI:EU:C:2019:529, para. 120.

152 Joined Cases C585/18, C624/18 and C625/18, A.K. (C585/18) v Krajowa Rada Sadownictwa and CP (C624/18), DO (C625/18) v Sąd Najwyższy (C624/18 and C625/18), joined party Prokurator Generalny zastępowany przez Prokurature Krajowa, Opinion of Advocate General Tanchev delivered on 27 June 2019, ECLI:EU:C:2019:551, para. 157.

153 Thienel (2010) 85.

154 Such as, for instance, the principles of the effectiveness and equivalence of the national remedies, effectives access to the court, foreseeability, legal certainty or providing reasons for judicial decisions. In this sense, see for example Anthony (2011) 51-70, or Ravo (2012) 103-06. 
and procedure of the national courts always remained with the national authorities. ${ }^{155}$ It could be mentioned here that even $A S J P$ has already had rather far-reaching consequences for the Hungarian judicial system. ${ }^{156} \mathrm{~A}$ wave of international critique followed this judgement in view of the ongoing reform of administrative courts system. On 12 December 2018, the Hungarian Parliament passed two laws establishing a separate system of administrative courts, with its own high court and its own judicial council that was set to begin its operation on 1 January 2020 and would have been supervised by the Minister of Justice. ${ }^{157}$

For instance, the analysis presented by the Venice Commission report mentions that the Minister of Justice is given a central role, with commensurate powers, in determining of the scale of those courts, the selection of future judges and the first heads of $\operatorname{court}^{158}$ which raise concerns on the separation of judicial and executive powers in Hungary. ${ }^{159}$ As a result, the Hungarian government decided to repeal the act passed in December 2018, mentioning that all statements made in connection with the administrative courts are null and void. ${ }^{160}$ The explanatory note on the proposal to repeal the Act on Administrative Courts states that this amendment aims to guarantee that the ongoing reform of the administrative justice does not hamper the efforts of reassuringly settling the disputes about the unfounded criticisms against Hungary's rule-of-law situation. ${ }^{161}$ Thus, the impact of the CJEU's Polish Rule of Law decisions is likely to be even more significant as the courts reform remains a central point of the Commission's proposal to invoke Art. 7 TEU procedure and, more generally, of the continuing political EU's dialogue with the Polish government.

\section{CONCLUSIONS}

This paper sheds light on the substance of the Rule of Law concept in EU Law, the legal reasoning adopted by the European Commission (Poland) and by the Parliament (Hungary) proposals in accordance with Art. 7(1) TEU submitted to the Council. Moreover, the author discusses the parallel developments in the CJEU's case-law - such as the $L M / M L$, Torubarov lines of reasoning as well as the judgements on the ongoing reform of the Polish Supreme Court and Ordinary courts. The main arguments were that the legal reasoning adopted by the key EU's institutions - the European Commission, Parliament and the Court of Justice of the European Union - does not seem to be coherent or completely consistent with the benchmarks previously developed in the ROFL Framework (2014) or the Venice Commission Checklist (2016).

155 Art. 5 TEU. In this sense, see for example Galetta (2018) link 14.

156 Kovaks ( 2019) link 15.

157 Act CXXXI of 2018 on the entry into force of the Act on administrative courts and certain transitional rules (repealed by Act LXI of 2019 on 9 July 2019).

158 European Commission for Democracy through Law (Venice Commission). Hungary: Opinion on the law on administrative courts and on the law on the entry into force of the law on administrative courts and certain transitional rules. Adopted by the Venice Commission at its $118^{\text {th }}$ Plenary Session (Venice, 15-16 March 2019) CDL-AD(2019)004, 8-20.

159 European Commission for Democracy through Law (Venice Commission). Hungary: Opinion on the law on administrative courts and on the law on the entry into force of the law on administrative courts and certain transitional rules. Adopted by the Venice Commission at its $118^{\text {th }}$ Plenary Session (Venice, 15-16 March 2019) CDL-AD(2019)004, 24-26.

160 Act LXI of 2019 postponing the entry into force of the Act on administrative courts (as in force on 9 July 2019).

161 Biro (2019) link 16. 
The Commission's proposal is based on sound legal reasoning and thoughtful analysis of the Polish legislation on the judicial reform, while the arguments revealed by the Sargentini report, covering also factors of socio-economic nature (the legislation on the conflicts of interest of the Hungarian Parliament members, homelessness, unemployment benefits) seems less convincing in view of the scope and substance of Arts. 2 and 7 TEU. Although the legal reasoning of the European Parliament's submissions could be questioned, the legitimacy of the report seems to be beyond doubt. However, for the report to pass, it required the backing of an absolute majority of MEPs and a two-thirds majority in the vote itself. $^{162}$ The text was approved with 448 votes in favour, 197 against and only 48 abstentions. ${ }^{163}$ Hungary made an attempt to favour the reconsideration of the vote outcome $^{164}$ but the Government's argumentation does not seem convenient i.e., the European Parliament violated its own rules of procedure while adopting the Sargentini report. ${ }^{165}$

This is a possible indication of the deeper issue - the questionable effectiveness of the Rule of Law concept as a tool to address the multiple challenges (including socio-economic issues) arising on the current stage of the Union's legal integration. Regardless of the outcomes of the Polish and Hungarian cases, these first attempts to invoke the 'nuclear option' of Art. 7 TEU are likely to leave more questions than answers for the EU Member States. In view of this premise, the application of the $L M / M L$ formula could be rather problematic. The CJEU's step away ('a real risk of an infringement of the right to a fair trial') from the European Convention-based benchmarks of the assessment of the right to a fair trial violation ('real risk of a flagrant denial of justice') might potentially require further interventions from both of the European Courts.

The CJEU's first attempts to tackle these challenges also demonstrated a lack of consistency in the judicial practice. In the Torubarov case, the CJEU carefully avoided mentioning the Rule of Law concept and maintained a middle-ground attitude whilst elaborating on the right of the asylum seekers to an effective remedy (Art. 46 of the Asylum Procedures Directive) primarily in light of the direct effect of EU Law within national legal systems. At the same time, the Court's defensive approach towards the judicial independence as an integral part of the Rule of Law principle in EU Law is likely to add more complexity to the overall picture. The outcomes of the earlier ASJP case already had very significant impact on the EU Member State's domestic laws - such as, for instance, the abolishment (or at least a postponement) of the administrative courts reform in Hungary. In any case - as indicated by the Law on the Supreme Court case - the CJEU is likely to further develop the ASJP approach while making final decisions in subsequent cases on the judicial system reform in Poland, providing rather generous guarantees of judicial independence - thus paving the way to the Council decision(s) on the launch of Art. 7 TEU procedure in the Polish and/or Hungarian cases.

162 Art. 7 TEU.

163 [Text adopted by Parliament, single reading] European Parliament resolution of 12 September 2018 on a proposal calling on the Council to determine, pursuant to Article 7(1) of the Treaty on European Union, the existence of a clear risk of a serious breach by Hungary of the values on which the Union is founded (European Parliament Official Website, 12 September 2018) $<$ https:// oeil.secure.europarl.europa.eu/oeil/popups/summary.do?id=1552104\&t=e\&l=en $>$ accessed 31 July 2019.

164 Case C-650/18, Hungary v Parliament (action brought on 17 October 2018).

165 Kochenov and Bard (2019) 5. 


\section{LITERATURE}

Arnardóttir, O. M., 'Res Interpretata, Erga Omnes Effect, and the Role of the Margin of Appreciation in Giving Domestic Effect to the Judgments of the ECtHR' (2017) 28 European Journal of International Law 819-43.

Arnull, A., 'The Principle of Effective Judicial Protection in EU law: An Unruly Horse?' (2011) 1 European Law Review 51-70.

Besselink, L., 'The Bite, the Bark and Howl: Art. 7 TEU and The Rule of Law Initiatives' in Jakab, András and Kochenov, Dimitry (eds), The Enforcement of EU Law and Values: Ensuring Member States' Compliance (OUP 2017).

Christoffersen, J., Fair Balance: A Study of Proportionality, Subsidiarity and Primarity in the European Convention on Human Rights' (BRILL 2009).

Eppler, A., Hackhofer, A. and Maurer, A., 'The Multilevel Rule of Law System of the European Union: Eked Out, Contested, Still Unassured' in Antoniolli, Luisa, Bonatti, Luigi, Ruzza, Carlo (eds), Highs and Lows of European Integration: Sixty Years After the Treaty of Rome (Springer 2018).

Gárdos-Orosz, F., 'Constitutional Justice in Credit Crises. The Hungarian Case' (2018) 1 SüdostEuropa 94-118.

Gáspár-Szilágyi, Sz., 'Joined Cases Aranyosi and Căldăraru: Converging Human Rights Standards, Mutual Trust and a New Ground for Postponing a European Arrest Warrant' (2016) 24(2) European Journal of Crime, Criminal Law and Criminal Justice 112-21.

Gateva, E., European Union Enlargement Conditionality (Palgrave Macmillan 2015).

Halmai, G., 'The Application of European Constitutional Values in EU Member States The Case of the Fundamental Law of Hungary' (2018) 2 European Journal of Law Reform 10-34.

Halmai, G., 'The Possibility and Desirability of Rule of Law Conditionality'(2018) Hague Journal on the Rule of Law 171-88.

Hamuák, O., National Sovereignty in the European Union: View from the Czech Perspective (Springer 2016).

Hillion, C., 'Enlarging the European Union and deepening its fundamental rights protection' (2013) 11 SIEPS European Policy Analysis 1-16.

Hillion, C., 'Overseeing the Rule of Law in the EU' in Closa, Carlos, Kochenov, Dimitry (eds), Reinforcing Rule of Law Oversight in the European Union (CUP 2016).

Hoffmann-Riem, W., 'The Venice Commission of the European Council - Standards and Impact' (2014) 25(2) The European Journal of International Law 579-97.

Jakab, A., 'The EU Charter of Fundamental Rights as the Most Promising Way of Enforcing the Rule of Law against EU Member States' in Closa, C., Kochenov, D. (eds), Reinforcing Rule of Law Oversight in the European Union (CUP 2016).

Kochenov, D. and Bárd, P., 'The Last Soldier Standing? Courts vs. Politicians and the Rule of Law Crisis in the New Member States of the EU', University of Groningen Faculty of Law Research Paper Series No. 5/2019.

Mangiameli, S. and Saputelli, G., 'Commentary on Article 7 TEU [The Principles of the Federal Coercion]' in Blanke, H.-J., Mangiameli, S. (eds), 'The Treaty on European Union: A Commentary' (Springer 2013).

Nagy, B., 'From Reluctance to Total Denial: Asylum Policy in Hungary 2015-2018' in Stoyanova, V. and Karageorgiou, E. (eds), The New Asylum and Transit Countries in Europe during and in the Aftermath of the 2015/2016 Crisis (BRILL 2018).

O'Cinneide, C., 'Completing the picture: the complex relationship between EU anti-discrimination law and Social Europe' in Countouris, Nicola, Freedland, Mark, Freedland, Robert (eds), Resocialising Europe in a Time of Crisis (CUP 2013).

Pech, L., 'A Union Founded on the Rule of Law: Meaning and Reality of the Rule of Law as a Constitutional Principle of EU Law' (2010) 6 European Constitutional Law Review 359-96.

Pech, L., 'The Rule of Law as a Constitutional Principle of the European Union' (2009) 4 Jean Monnet Working Paper.

Prechal, S. and Widdershoven, R., 'Redefining the Relationship between "Rewe-effectiveness" and Effective Judicial Protection' (2011) 2 (4) Review of European Administrative Law 31-50. 
Rauchegger, C., 'The Interplay Between the Charter and National Constitutions after Åkerberg Fransson and Melloni: Has the CJEU Embraces the Challenges of Multilevel Fundamental Rights Protection?' in De Vries, S., Bernitz, U., Weatherill, S. (eds), The EU Charter of Fundamental Rights as a Binding Instrument: Five Years Old and Growing (Bloomsbury Publishing 2015).

Ravo, L. M., 'The role of the Principle of Effective Judicial Protection in the EU and its Impact on National Jurisdictions' (2012) 1 Sources of Law and Legal Protection (EUT Edizioni Università di Trieste) 101-25.

Reich, N., 'Judicial Protection in the EU' (2005) 1(2) Revista Direito GV 111-36.

Sadurski, W., 'EU Enlargement and Democracy in New Member States' in Paulussen, C., Takacs, T., Lazić, V. (eds), Fundamental Rights in International and European Law: Public and Private Law Perspectives (Springer 2016).

Schroeder, W., 'The European Union and the Rule of Law - State Affairs and Ways of Strengthening' in Schroeder, W. (ed), 'Strengthening the Rule of Law in Europe. From a Common Concept to Mechanisms of Implementation' (Bloomsbury Publishing 2016).

Šelih, J., Bond, I., Dolan, C., 'Can EU funds promote the rule of law in Europe?' (2017) CER Working Papers, November 2017.

Šišková, N., 'Current mechanism of human rights protection at the level of the EU, their peculiarities and future prospects' (2016) 3 International Multidisciplinary Scientific Conference on Social Sciences \& Arts SGEM 805-13.

Spendzharova, A. and Vachudova, M. A., 'Strategies for Integration in the EU's Pre-Accession Process: Reshaping Party Positions and State Institutions' in Bruszt, L. and McDermott, G. (eds), Leveling the Playing Field: Transnational Regulatory Integration and Development (OUP 2014)

Taborowski, M., 'The European Commission launches Art. 7 TEU proceedings against Poland for breach of Rule of Law' (2018) 38(1) Quaderni Costituzionali 238-39.

Tawhida, A., 'The EU's Protection of ECHR Standards: More Protective than the Bosphorus Legacy?' in Green, J., Waters, C. (eds), Adjudicating International Human Rights Essays in Honour of Sandy Ghandhi (Martinus Nijhoff Publishers 2014).

Thienel, R., 'Organisation and function of the European Court of Justice (Court of Justice of the European Union), With special emphasis on the procedure concerning preliminary rulings' (2010) 27 Ritsumeikan Law Review 81-99.

Von Bogdandy, A., Antpöhler, C., Ioannidis, M., 'Protecting EU values Reverse Solange and the Rule of Law Framework' in Jakab, A., Kochenov, D. (eds), The Enforcement of EU Law and Values: Ensuring Member States' Compliance (OUP 2017).

Von Bogdandy, A., Kottmann, M., Antpöhler, C., Dickschen, J., Hentrei, S., Smrkolj, M., 'Reverse Solange-Protecting the essence of fundamental rights against EU Member States' (2012) 2 Common Market Law Review 489-519.

Von Bogdandy, A., Spieker, L. D., 'Countering the Judicial Silencing of Critics - Article 2 TEU Values, Criminal Liability and Reverse Solange' (2019) Max Planck Institute for Comparative Public Law \& International Law (MPIL) Research Paper No. 2019-08.

Von Danwitz, T., 'The Rule of Law in the Recent Jurisprudence of the ECJ' (2014) 37(5) Fordham International Law Journal 1314-16.

\section{LINKS}

1. Michelot, M., 'France and the V4 in a multi-speed Europe: rough times ahead?' (EUROPEUM, 15 August 2017) <http://europeum.org/data/articles/mm-francev4pp.pdf > accessed 31 July 2019.

2. Von Bogdandy, A., Kottmann, M., Antpöhler, C., Dickschen, J., Hentrei, S. and Smrkolj, M. 'A Rescue Package for EU Fundamental Rights-Illustrated with Reference to the Example of Media Freedom' (UK Constitutional Law Website, 18 February 2012) < http://ukconstitutionallaw. org/2012/02/18/a-rescue-package-for-eu-fundamental-rights $>$ accessed 31 July 2019.

3. Bárd, P., 'EU responses to rule of law backsliding in the Member States - the Hungarian case' (EUROPATARSASAG, 15 March 2017) <https://www.europatarsasag.hu/sites/default/files/openspace/documents/magyarorszagi-europa-tarsasag-rolmet.pdf $>$ accessed 31 July 2019. 
4. Olivier D. S., 'Infringement Proceedings as a Tool for the Enforcement of Fundamental Rights in the European Union' (Open Society European Policy Institute, October 2017), <https://www. opensocietyfoundations.org/publications/infringement-proceedings-tool-enforcementfundamental-rights-european-union> accessed 31 July 2019.

5. Ferraro, F. and Carmona, J., 'Fundamental Rights in the European Union: In Depth Analysis' (EPRS, 14 March 2015), <http://www.europarl.europa.eu/RegData/etudes/IDAN/2015/554168/ EPRS_IDA(2015)554168_EN.pdf> accessed 31 July 2019.

6. Pech, $\overline{\mathrm{L}}$. and Wachowiec, $\overline{\mathrm{P}}$., ' 1095 Days Later: From Bad to Worse Regarding the Rule of Law in Poland (Part I)' (VERFASSUNGSBLOG, 13 January 2019) <https://verfassungsblog. de/1095-days-later-from-bad-to-worse-regarding-the-rule-of-law-in-poland-part-i> accessed 31 July 2019.

7. Pech, L. and Platon, S., 'Rule of Law backsliding in the EU: The Court of Justice to the rescue? Some thoughts on the ECJ ruling in Associação Sindical dos Juízes Portugueses' (EULAWANALYSIS, 13 March 2018) <http://eulawanalysis.blogspot.com/2018/03/rule-of-lawbacksliding-in-eu-court-of.html> accessed 31 July 2019.

8. Carrera, S. and Bárd, P., 'The European Parliament vote on Article 7 TEU against the Hungarian government: Too late, too little, too political?' (CEPS, 14 September 2018) <https://www.ceps. eu/system/files/EP\%20vote\%20on\%20Article7 0.pdf> accessed 15 July 2019.

9. Information sheet of the Hungarian Government on the issues raised by the draft report of Judith Sargentini on 'a proposal calling on the Council to determine, pursuant to Article 7(1) of the Treaty on European Union, the existence of a clear risk of a serious breach by Hungary of the values on which the Union is founded' (UJHELYI, October 2018) <http://ujhelyi.eu/wp-content/ uploads/2018/05/Information-sheet-of-the-Hungarian-Government-on-the-issues-raised-by-th.... pdf $>$ accessed 31 July 2019.

10. The European University Institute Centre For Judicial Cooperation, 'Aranyosi and Căldăraru, judgment of 5 April 2016' (European University Institute Official Website, 5 May 2016) <http:// judcoop.eui.eu/data/?p=data\&idPermanent=401> accessed 31 July 2019.

11. Moraru, M., Strazzari, D., Penasca, S., 'The added value of Art. 47 CFR and general principles of EU law in asylum and immigration adjudication' (REJUS, 24 October 2017) $<$ https://www. rejus.eu/sites/default/files/content/event/files/rejus_presentation_trento_defi_mail_ simone_21.25.pdf $>$ accessed 15 July 2019.

12. Simonelli, M. A., 'Thickening up judicial independence: the ECJ ruling in Commission v. Poland (C-619/18)' (European Law Blog, 8 July 2019) <http://europeanlawblog.eu/2019/07/ 08/thickening-up-judicial-independence-the-ecj-ruling-in-commission-v-poland-c-619-18/> accessed 31 July 2019.

13. Allan R., 'The European Court of Justice: Do all roads lead to Luxembourg?' (CEPS Policy Insights, February 2019) < לhttps://www.ceps.eu/wp-content/uploads/2019/02/PI2019_03_AR_ ECJ_0.pdf $>$ accessed 31 July 2019.

14. Galetta, D.-U., 'The principle of Procedural Autonomy of EU Member States and the impact of EU law on National Judicial Procedure' (EJTN Website, 15 March 2018) <http://www.ejtn.eu/ PageFiles/16773/ProceduralAutonomyEU-MS-2018.pdf> accessed 31 July 2019.

15. Kovaks, Z., 'Hungarian Government postpones the introduction of administrative courts due to international pressure' (Index Hu Website, 3 June 2019) <https://index.hu/english/2019/06/03/ administrative_courts_postponed_hungary_fidesz_government_eu_epp/ $>$ accessed 31 July 2019.

16. Biro, M., 'Speaker of the Hungarian Parliament admits: Administrative courts not off the table' (Other News Website, 10 July 2019) <http://www.other-news.info/2019/07/speaker-of-thehungarian-parliament-admits-administrative-courts-not-off-the-table> accessed 31 July 2019. 